

\title{
Relationship between Teachers' Attitudes and the Utilization of Instructional Materials in Pre-Primary Schools in Kenya
}

\author{
Joseph K. Waigera*,1, Maureen Mweru, PhD ${ }^{1,2} \&$ Lucy Ngige, PhD ${ }^{1,3}$ \\ ${ }^{1}$ Kenyatta University, P. O. Box 43844 - 00100, Nairobi, Kenya. \\ * ORCID: https://orcid.org/0000-0003-0895-985X; Author for Correspondence Email: jkwaigera@ gmail.com \\ ${ }^{2}$ ORCID: https://orcid.org/0000-0001-8885-6484 \\ ${ }^{3}$ ORCID: https://orcid.org/0000-0003-1750-1496
}

Article DOI: $\underline{\text { https://doi.org/10.37284/eajes.2.1.189 }}$

\section{Date Published: ABSTRACT}

07 August 2020 The purpose of this research was to establish whether there was a significant relationship between teachers' attitudes and levels of utilization of instructional

Keywords: materials (IM) in Pre-Primary Schools in Kenya. The study adopted the

Early Childhood

Education,

Instructional Materials, Pre-Primary Schools,

Teachers' Attitudes, Ecological Systems Theory by Urie Bronfenbrenner. The study used a crosssectional survey research design and data was collected through selfadministered questionnaires. A sample of 164 teachers comprising of $76.2 \%$ females and $23.8 \%$ males participated in the study. Results established that $86.4 \%$ of the teachers had positive attitudes towards the instructional practice. Kenya. In terms of utilization of instructional materials, the researchers determined that $62.1 \%$ of the respondents achieved high levels while $37.9 \%$ attained low levels of utilization of instructional materials across the Early Childhood Development Education (ECDE) activity areas. The Chi-Square results revealed that there was a statistically significant relationship between teachers' attitudes and utilization of instructional materials $\left(\chi^{2}=4.094 ;\right.$ d.f. $\left.=2 ; p=0.043\right)$. Further analysis using the regression test revealed that there was a statistically significant relationship between teachers' positive attitudes and levels of utilization of instructional materials $(\beta=0.516 ; p=0.001)$. These findings established that teachers who had positive attitudes attained higher levels of utilization of instructional materials in their classrooms compared to their counterparts who had negative attitudes. Therefore, it was concluded that teachers' attitudes were a significant factor in promoting the utilization of instructional materials in ECDE activities. This implies that a positive attitude is an important attribute of a pre-primary school teacher. Therefore, there is a need to inculcate positive attitudes towards the utilization of instructional materials among teachers during pre-service and 
in-service training sessions to promote the best practices in instruction at the pre-primary school level.

\begin{abstract}
APA CITATION
Waigera, J., Mweru, M., \& Ngige, L. (2020). Relationship between Teachers' Attitudes and the Utilization of Instructional Materials in Pre-Primary Schools in Kenya. East African Journal of Education Studies, 2(1), 92-104. https://doi.org/10.37284/eajes.2.1.189.

\section{CHICAGO CITATION}

Waigera, Joseph, Maureen Mweru, and Lucy Ngige. 2020. "Relationship between Teachers' Attitudes and the Utilization of Instructional Materials in Pre-Primary Schools in Kenya". East African Journal of Education Studies 2 (1), 92-104. https://doi.org/10.37284/eajes.2.1.189.
\end{abstract}

\title{
HARVARD CITATION
}

Waigera, J., Mweru, M. and Ngige, L. (2020) “Relationship between Teachers' Attitudes and the Utilization of Instructional Materials in Pre-Primary Schools in Kenya", East African Journal of Education Studies, 2(1), pp. 92-104. doi: 10.37284/eajes.2.1.189.

\section{IEEE CITATION}

J. Waigera, M. Mweru, and L. Ngige, "Relationship between Teachers' Attitudes and Utilization of Instructional Materials in Pre-Primary Schools in Kenya”, EAJES, vol. 2, no. 1, pp. 92-104, Aug. 2020.

\section{MLA CITATION}

Waigera, Joseph, Maureen Mweru, and Lucy Ngige. "Relationship between Teachers' Attitudes and Utilization of Instructional Materials in Pre-Primary Schools in Kenya”. East African Journal of Education Studies, Vol. 2, no. 1, August 2020, pp. 92-104, doi:10.37284/eajes.2.1.189.

\section{INTRODUCTION}

Pre-primary education is an integral part of Kenya's system of education and it forms the foundation of formal education. According to Kenya's competency-based curriculum (Kenya Institute of Curriculum Development, 2017), formative education equips learners with important early experiences that assist an individual in developing holistically in life. The school curriculum should help in transmitting knowledge, attitudes, and values to children. Anini (2011) observed that instructional materials for children should appeal to their natural curiosities as well as the desire to explore and experiment. According to Mayer (2005), children are motivated by handling instructional materials which enable them to relate better with the concepts being taught.

Omayio (2013) observed that instructional materials ought to stimulate the child's natural curiosity, thus enabling their desire to explore the world, which in turn provides children with opportunities to broaden their knowledge. There is inadequate information in Kenya on the effect of teachers' attitudes on the utilization of instructional materials, thereby justifying the need for such a study in pre-primary schools in Kenya. Therefore, the purpose of the study was to establish the relationship between teachers' attitudes and utilization of instructional materials in pre-primary schools. The objectives of the study were to: determine the teachers' perceived benefits of using instructional materials in ECDE, establish the teachers' perceived barriers to the use of instructional materials in ECDE, to determine the teachers' attitudes towards utilization of instructional materials in ECDE, to establish the levels of utilization of instructional materials in ECDE and finally to establish whether there was any statistically significant relationship between teachers' attitudes and utilization of instructional materials in ECDE. The null hypothesis stated that there was no statistically significant relationship between teachers' attitudes and utilization of instructional materials in ECDE.

\section{LITERATURE REVIEW}

\section{Pre-Primary School Teachers' Attitudes}

In this study, pre-primary school teachers' attitudes refer to the teachers' mind-set towards instructional practice and the use of instructional materials in ECDE. Cavas, Karaoglan, and Kisla (2010) explored primary school science teachers' attitudes 
towards Information and Communication Technology (ICT) in education. The results indicated that the science teachers who had positive attitudes had higher levels of utilization of ICT in their teaching compared to those who had negative attitudes. A similar study was conducted by Bakr (2011) on the attitude of Egyptian teachers towards the use of computers in public schools. The results showed that teachers' who had positive attitudes towards the use of technology, applied ICT related learning resources effectively compared to those who had negative attitudes towards the use of educational technology in teaching.

Al-Zaidiyeen, Mei and Fook (2010) did a study to investigate teachers' attitudes towards the use of ICT in Jordan schools. The study established that there was a significant positive correlation between teachers' attitudes and the level of ICT application in schools. A similar study was carried out in Nigeria by Onadiran and Onadiran (1981). The results revealed that teachers were generally not interested in developing materials for use in instruction since they had negative attitudes towards teaching, lacked training and experience. The report further indicated that there was an acute shortage of instructional materials such as books, magazines, newspaper cuttings, projected materials, and radio lesson programs in most schools. A study done in Kenya by Mwololo et al. (2011) showed that teachers' attitude towards instructional materials was related to the use of the media in teaching. The researcher surveyed preschool teachers' attitudes towards the use of instructional visual media in Kibwezi District, Eastern Province, Kenya. The results showed that there was a significant relationship between preschool teachers' attitudes and use of visual media in instruction in mathematics, science, social studies, music, movement, art and craft. It was concluded that pre-school teachers' positive attitude towards instructional practice acted as a motivation to use visual media in teaching.

\section{Utilization of Instructional Materials in Pre- primary Schools}

According to Anini (1997), instructional materials play an important role in the education of children at the pre-school level. Learning aids help pupils to understand what is being taught when they see and handle the actual objects. These materials provide opportunities for children to broaden and deepen their knowledge by providing a variety of first hand developmentally appropriate experiences. Learning materials help children to acquire symbolic knowledge by handling and manipulating concrete objects in their learning experiences. According to Odejobi (2014), instructional material management is a crucial component of the entire classroom control and management. The introduction of instructional materials in a classroom usually generates excitement in pupils that may be followed by noise, undue movement of pupils, chairs and tables as the pupils participate in the lesson. The instructional materials and aids are used to supplement and complement the teacher's verbal effort.

Odejobi (2013) further observed that appropriate instructional materials are an important tool that every teacher must use in the teaching and learning process. He established six major functions of instructional aids for early learners namely: a) to make a concrete basis for conceptual thinking and reduction of meaningless words and responses by pupils; b) to generate a high degree of interest in learning by pupils; c) to make learning more paramount; d) to offer a reality of experience which stimulates self-activity on the part of the pupils; e) to form the basis of continuity of thought and this is especially true of motion pictures; $f$ ) to provide an experience not easily obtained using other methods of instruction to early learners.

These findings are supported by a study done by Chepkemoi (2016) on factors influencing the selection of instructional resources used in public pre-schools in Eldoret municipality in Kenya the researcher reported that instructional materials were used to aid and facilitate teaching process for better understanding of concepts in pre-schools. The researcher determined that there were six key functions of instructional resources for early learners namely: a) to stimulate learners interest and attention in pupils throughout the lesson; b) to make learning real and enjoyable for children when they manipulate the learning materials; c) to play with the materials; d) to help in the development of body muscles as children manipulate the learning materials; e) to help in class control; f) to keep children busy while handling the materials even in 
the absence of the teacher' g) to keep children engaged in continuous learning activities by observing materials displayed on the classroom walls, while others observe pictures of different kinds which make children be more creative and imaginative in their learning experience.

According to Maddahian and Bird (2003), instructional materials are resources used to make learning easy, enjoyable, practical, and meaningful to the learner. However, lack of confidence and negative attitudes in teachers hinders the use of instructional resources in teaching. In Ethiopia, Afework and Asfaw (2014) researched the availability of school facilities and their impacts on the quality of education in Ethiopia. Results showed that school facilities and instructional materials were not adequate in quantity and quality, thereby creating a challenge in teaching and learning activities. Chepkonga (2017) did a study on the influence of learning facilities on the provision of quality education in public early childhood development education centres in West Pokot County, Kenya. She concluded that without learning facilities in the school, effective learning could not take place. Kimui (1990) did a study on the availability and use of teaching and learning resources in primary teachers' colleges in Kenya. The findings showed that equipment and materials available in resource centres were under-utilized, and tutors were not confident in the use of instructional resources.

A study was done by Digolo (1986) on the utilization of community resources by primary school teachers indicated that the actual utilization of community resources by primary schools to provide learning experience was a major factor of concern. The main objective of the study was to identify and classify resources that could be used by primary schools to provide a meaningful learning experience. The findings revealed the low use of community resources by the majority of the primary school teachers. The study also revealed that the amount of support for teaching and learning in primary schools was inadequate. Lack of learning resources contributed to poor retention in children. To ensure materials were available in schools, stakeholders such as parents, teachers, and the community should be involved in the development of instructional materials for learners.
A study was done by Karimi (2012) on instructional strategies and utilization of learning resources in teaching social studies revealed that lack of learning resources led to low creativity among learners because they were not actively involved in the class. Lack of learning resources also led to the lecture method and what was learned was quickly forgotten. The researcher found that there was a lack of adequate resource materials for teaching social studies. MSei (1985) surveyed resources used for teaching Kiswahili language in selected primary schools in Machakos, Kenya. The study found that initially, the Ministry of Education used to provide textbooks and wall charts as aids for teaching in the past but had stopped doing so due to lack of funding. It was further reported that teachers knew the importance of using aids in teaching but had not implemented it in teaching and learning of Kiswahili. It was also found that teachers did not properly store their materials and did not have a proper recording system. Due to a lack of interest in teaching Kiswahili, the teachers did not meet to share ideas on how to produce and use instructional materials in teaching languages. It was further revealed that teachers' advisory centres whose mandate was training teachers on how to develop instructional resources were also not in operation. Previous studies showed that there were inadequate teaching and learning resources in primary schools and primary teachers' colleges. Wambua (1988), who researched on the utilization of resources in training teacher trainees, found that there was a lack of teaching and learning materials for environmental education in primary teachers' colleges in Kenya.

\section{Theoretical Framework}

This research applied the ecological systems theory by Bronfenbrenner (1979) as the foundational theoretical framework for this study. This theory describes the learning process from both the environmental perspective as well as the interaction of learners with the instructional materials. According to the ecological systems theory, the development process of a child takes place in varying environments. Each environment has a significant effect on a child's development. Preprimary school teachers are part of the school environment in which the child's developmental process occurs. The child is enrolled in early 
childhood development centres where the teacher inculcates knowledge, attitudes and skills to the pupils. The teachers in this setting have a responsibility to make the pre-school an enabling environment for effective learning.

\section{METHODOLOGY}

The study applied a cross-sectional survey research design since data was gathered at one point in time. According to Mugenda and Mugenda (2003), a descriptive survey attempts to describe characteristics of a phenomenon that cannot be directly observed, such as people's attitudes on varied subjects. This design was considered as appropriate for the current study since the researchers wanted to establish the relationship between teachers' attitudes and the levels of utilization of instructional materials in pre-primary schools in Nyeri County, Kenya. The sample was drawn from four Sub-Counties in Nyeri County that were randomly selected to participate in the study. The target population was a total of 270 public preprimary school teachers in Nyeri County. A random sample of 164 pre-primary school teachers was selected to participate in the study. Data were collected through a self-administered structured questionnaire filled by the teachers on an agreed scheduled date in the participating schools.

A pre-test was conducted on a sample of 10 teachers who were consequently excluded from the main study. The reliability of the research instrument was determined by the use of the splithalf reliability method. The findings of the pre-test results were computed, and then the correlation between the two halves was determined. Cronbach alpha was used to compute the reliability coefficient. A coefficient of 0.716 was obtained, indicating that the internal consistency of the items met the recommended threshold of 0.70 (Mugenda \& Mugenda, 2003). In terms of ethical considerations, approvals were obtained from the Ethics and Review Committee, and research authorization obtained from the National Centre for Science, Technology and Innovation (NACOSTI). Permission was also granted by the relevant County authorities, including Nyeri County Director of Education and the respective school head-teachers, before collecting data from the participants.
The independent variable for this study was teachers' attitudes towards the use of instructional materials in pre-primary schools. A set of three research questions were used to assess teachers' attitudes namely: one set of five statements measuring teachers' perceived benefits of using instructional materials and the second set of five questions investigating the perceived barriers to teachers' use of instructional materials, and a final set of 10 statements measuring teachers' attitudes towards the use of instructional materials in ECDE activity areas. To establish the rating of selfappraisal of teachers' attitudes towards the use of instructional materials, scores of responses to the 5 items along a 3-point Likert scale were computed. The Likert scale responses on the perceived benefits of the use of instructional materials were coded as 3 scores for "Agree (A)", 2 scores for "Neither Agree nor Disagree (NAD)," and one (1) score for "Disagree (D)."

Computation of scores for the second set of five questions investigating the perceived barriers to use of instructional materials, the reverse order of scoring was used for the perceived barriers where one (1) score was awarded for "Agree", 2 scores for "Neither Agree nor Disagree," and 3 scores for "Disagree" because the statements were stated in the negative form. For example, "I do not allow pupils to handle learning materials because they will get spoilt". The minimum and maximum possible scores a respondent could attain for the 5 items were 5 and 15 respectively. Using this analytical framework, respondents who attained 510 scores were classified as having a negative attitude towards the use of instructional materials, and respondents who attained 11-15 scores were classified as having a positive attitude towards the use of instructional materials. The third set of items measuring the rating of teachers' attitudes towards instructional materials in ECDE activity areas ranged from the lowest score of one (1) to a maximum of 5 scores. The teachers who scored at least half of the scores or more $(>2.5)$ points were categorized as having a positive attitude, while those who attained less than half of the expected mean score $(<2.5)$ were categorized as having a negative attitude towards the use of instructional materials in ECDE activities. 
The dependent variable for this study was the levels of utilization of instructional materials in preprimary schools. To establish the levels of utilization of instructional materials in pre-primary schools, scores of responses to eight items along a 5-point Likert scale were calculated. The items assessed the extent to which teachers utilized instructional materials across ECDE activity areas. The responses on the Likert scale were coded as: "1=None at all", " $2=$ Little Extent", " $3=$ Moderate Extent," "4=Large Extent" and " $5=$ Very Large Extent". The minimum and maximum possible scores a respondent could attain for the 8 items were 8 and 40, respectively. Using this analysis, respondents who attained between 8-24 scores were classified as low users of IM and respondents who attained 25-40 scores were classified as high users of IM.

\section{RESULTS}

A sample of 164 teachers participated in the study. In terms of gender, $76.2 \%$ were female and $23.8 \%$ were male teachers. The age of the teachers ranged from 21 to 55 years with a mean age of 35 years. In terms of education, $90 \%$ had acquired tertiary levels of education, and $93 \%$ were professionally trained teachers in early childhood education (ECD) and only $7 \%$ were untrained teachers. The frequency distribution for the perceived benefits of using instructional materials is presented in Table 1 .

\section{Table 1: Distribution of teachers' perceived benefits of using instructional materials}

\begin{tabular}{|c|c|c|c|}
\hline Perceived Benefits of using IM & A (3) & NAD (2) & D (1) \\
\hline I improvise local materials to make learning interesting & $152(92.7)$ & $5(3.0)$ & $7(4.3)$ \\
\hline I cannot teach a new concept without teaching aids & $124(75.6)$ & $2(1.2)$ & $38(23.2)$ \\
\hline $\begin{array}{l}\text { It is the responsibility of the teacher to provide teaching } \\
\text { materials in every lesson }\end{array}$ & $134(81.8)$ & $2(1.2)$ & $28(17.0)$ \\
\hline $\begin{array}{l}\text { I believe pupils learn better when presented with learning } \\
\text { materials }\end{array}$ & $151(92.1)$ & $4(2.4)$ & $9(5.5)$ \\
\hline $\begin{array}{l}\text { I encourage pupils to handle materials to facilitate effective } \\
\text { learning }\end{array}$ & $149(90.9)$ & $2(1.2)$ & $13(7.9)$ \\
\hline Mean score & $142(86.6)$ & $5(3.0)$ & $17(10.4)$ \\
\hline
\end{tabular}

According to Table 1, the majority of the teachers $(86.6 \%)$ agreed on the perceived benefits of using instructional materials across all items assessed while $3.0 \%$ were neutral and $10.4 \%$ disagreed with all items assessed. These findings are supported by other researchers in early childhood education research. In evaluating the perception of the pedagogical value of picture books as an instruction media for teaching oral skills in pre-schools, Chacha, Mwanda and Midigo (2018) observed that majority of teachers believed in the value of picture books in making learning fun, presenting learners with opportunities to show their oral skills, stimulating learner creativity as well as encouraging collaborative learning. This portrays the willingness of teachers who have positive attitudes to using instructional materials to facilitate teaching and learning in ECDE. The result of the perceived barriers towards the use of instructional materials is presented in Table 2.

Table 2: Distribution of teachers' perceived barriers to the use of instructional materials

\begin{tabular}{|c|c|c|}
\hline Perceived barriers to the use of IM & NAD (2) & A (1) \\
\hline $\begin{array}{l}\text { I can only use commercially produced instructional materials for133 (80.7) } \\
\text { teaching ECDE }\end{array}$ & $1(0.6)$ & $30(18.7)$ \\
\hline Preparation of improvised instructional materials is time consuming100 (60.3) & $4(3.0)$ & $60(36.7)$ \\
\hline $\begin{array}{l}\text { I do not allow pupils to handle learning materials because they will140 (84.9) } \\
\text { get spoilt }\end{array}$ & $2(1.2)$ & $22(13.2)$ \\
\hline
\end{tabular}




\begin{tabular}{|c|c|c|}
\hline Perceived barriers to the use of IM & NAD (2) & A (1) \\
\hline $\begin{array}{l}\text { I teach pupils without instructional materials in some ECDE97 (59.2) } \\
\text { activities }\end{array}$ & $4(2.4)$ & $63(38.4)$ \\
\hline $\begin{array}{l}\text { It is the responsibility of the school management to provide } 115 \text { (69.5) } \\
\text { instructional materials for ECDE activities }\end{array}$ & $2(1.2)$ & $47(29.3)$ \\
\hline Mean score & $13(7.9)$ & $45(27.4)$ \\
\hline
\end{tabular}

According to Table 2, the majority of the teachers $(64.7 \%)$ disagreed with the perceived barriers to teachers' use of instructional materials implying that they had positive attitudes across all items assessed. About a quarter (27.4\%) strongly agreed that perceived barriers contributed to the non-use of instructional materials implying that they had a negative attitude and $7.9 \%$ neither agreed nor disagreed with the given statements which implied an indifferent attitude towards the use of instructional materials in pre-primary schools. These findings are supported by another researcher in early childhood studies. Abaya (2017) examined the influence of instructional materials on preschool children's learning achievement in number work in Kakamega County, Kenya. The results showed that teachers' reliance on commercially acquired materials not only constrained learning but also made learning more expensive and superficial instead of practical.

\section{Assessment of Teachers' Attitudes towards IM in ECDE}

The study sought to establish the teachers' attitudes towards the utilization of IM in each of the ECDE activity areas. The results of the rating of teachers' attitudes towards the use of instructional materials are presented in Table 3.

Table 3: Distribution of teachers' attitudes towards the utilization of instructional materials across ECDE activities

\begin{tabular}{lll}
\hline Variable & Mean & Std Dev. \\
\hline IMs in math activities help learners to understand concepts better & 3.71 & .997 \\
IMs make language activities interesting & 4.00 & .438 \\
IMs in science activities help learners to understand better & 3.71 & .997 \\
Use of IMs social studies activities motivates learners & 1.70 & 1.011 \\
Use of IMs in creative work makes learners active & 1.47 & 1.062 \\
Use of IMs in music \& movement activities helps learners to achieve the learning & 1.70 & 1.011 \\
outcomes & & \\
It is easy to get improvised materials for outdoor activities & 4.40 & .493 \\
IM helps teachers to be more effective in indoor activities & 3.40 & 2.022 \\
Use of IMs in teaching CRE motivates the learners & 2.94 & 2.124 \\
Use of IMs in life skills help teachers to be innovative & 3.71 & .997 \\
Overall Mean scores (N=164) & $\mathbf{2 . 5 3 3}$ & $\mathbf{1 . 0 1 6}$ \\
\hline
\end{tabular}

According to Table 3, the rating of teachers' attitudes towards instructional materials ranged from the lowest mean of 1.47 in creative work to a high mean of 4.40 in outdoor activities out of a maximum of 5 scores. The cut-off point used for categorizing teachers as having either positive or negative attitude was the overall mean rating of 2.533 with a standard deviation of 1.016. The teachers who scored 2.533 and above were categorized as having a positive attitude, while those who attained less than the overall mean of 2.533 were categorized as having a negative attitude towards the use of instructional materials in ECDE activities. The results for teachers' attitudes towards the use of instructional materials are presented in Table 4. 
Table 4: Distribution of teachers' attitudes towards instructional materials

\begin{tabular}{lll}
\hline Variable & Frequency $(\mathbf{N})$ & Percent (\%) \\
\hline Teachers with a positive attitude & 135 & 82.4 \\
Teachers with a negative attitude & 29 & 17.6 \\
Total & $\mathbf{1 6 4}$ & $\mathbf{1 0 0 . 0}$ \\
\hline
\end{tabular}

The results presented in Table 4 showed that the majority of teachers $(82.4 \%)$ had a positive attitude, while $17.6 \%$ had a negative attitude towards the use of instructional materials in ECDE. This implies that teachers who had positive attitudes towards teaching also took individual responsibility for providing instructional materials for their pupils. On the other hand, those teachers who had a negative attitude and perceived that the school management should provide instructional materials for ECDE activities did not take individual responsibility to develop or improvise locally available teaching and learning aids for their pupils. These findings are consistent with those of Bernard (2007) who observed that teachers' attitudes towards the utilization of instructional materials were critical for effective integration of instructional resources in teaching and learning at the pre-primary level. This finding is further supported by Omayio (2013) who observed that teachers who have too much classwork and school responsibilities might find selection, preparation and use of instructional materials too demanding unless they have the right attitude towards teaching in ECDE.

\section{Levels of Utilization of Instructional Materials in Pre-primary schools}

One of the objectives of this study was to establish the extent to which pre-primary school teachers' used instructional materials across the eight ECDE activity areas. To establish the extent to which teachers used instructional materials across ECDE activity areas, scores of responses to eight ECDE activity areas along a 5-point Likert scale were computed. The findings of the utilization of instructional materials across ECDE activity areas are presented in Table 5.

Table 5: Distribution of Utilization of instructional materials

\begin{tabular}{lllllll}
\hline Variable & \multicolumn{2}{l}{ Frequency (N) (Percent \%) } & & \\
ECDE Activity Area & $\begin{array}{l}\text { Mery } \\
\text { Little }\end{array}$ & $\begin{array}{l}\text { Little } \\
\text { Extent }\end{array}$ & $\begin{array}{l}\text { Extent } \\
\text { Exte }\end{array}$ & $\begin{array}{l}\text { Large } \\
\text { Extent }\end{array}$ & Very Large & Total \\
& $3(1.9)$ & $18(11.3)$ & $46(28.8)$ & $65(40.6)$ & $28(17.5)$ & $160(100)$ \\
Language & $1(0.6)$ & $22(13.0)$ & $44(27.0)$ & $40(25.2)$ & $52(32.7)$ & $159(100)$ \\
Math & $1(0.6)$ & $23(14.6)$ & $43(27.2)$ & $51(32.3)$ & $40(25.3)$ & $158(100)$ \\
Science & $1(0.6)$ & $35(22.0)$ & $42(26.4)$ & $51(32.1)$ & $30(18.9)$ & $159(100)$ \\
Social Studies & $2(1.2)$ & $27(16.8)$ & $28(17.4)$ & $51(31.7)$ & $53(32.9)$ & $161(100)$ \\
Creative Work & $7(4.4)$ & $26(16.3)$ & $43(26.9)$ & $57(35.6)$ & $27(16.9)$ & $160(100)$ \\
Music and Movement & $3(1.9)$ & $12(7.4)$ & $21(13.0)$ & $58(35.8)$ & $68(42.0)$ & $162(100)$ \\
Outdoor Activities & $0(0.0)$ & $3(27.3)$ & $1(9.1)$ & $2(18.2)$ & $5(45.5)$ & $11(100)$ \\
CRE \& Life skills & $8(6.6)$ & $16(13.3)$ & $24(26.6)$ & $32(26.6)$ & $40(33.3)$ & $120(100)$ \\
Mean Score & & & & & & \\
\hline
\end{tabular}

Results presented in Table 5 showed that $33.3 \%$ of the teachers used instructional materials to a very large extent. An equal proportion used IM to either a moderate or to a large extent, respectively $(26.6 \%)$, while $13.3 \%$ used IM to a limited extent $(6.6 \%)$ and a minimal extent. These results are similar to those obtained by Makokha (2017), who found out that $44.8 \%$ of the teachers in Bungoma East sub-county frequently used improvised instructional materials with $29.3 \%$ utilizing IM on a moderate level, while the rest minimally utilized the materials. The high rate of utilization of improvised instructional materials was attributed to the fact that they were readily available within the 
school environment. According to Adebayo and Adigun (2018), the use of instructional materials in schools in Federal Capital Territory in Abuja, Nigeria indicated that a majority of the teachers used instructional materials in teaching sciences as all the respondents indicated that there were instructional materials readily available and they had used them in their instructional exercises. These findings were verified by over $90 \%$ of the learners who indicated that their teachers used instructional materials in teaching.

\section{Levels of Utilization of Instructional Materials}

The minimum and maximum possible scores a respondent could attain for the 8 items presented in Table 5 were 8 and 40, respectively. Using this analysis, respondents who attained between 8-24 scores were classified as low users of IM and respondents who attained 25-40 scores were classified as high users of IM. The frequency distribution for the rating of levels of utilization of instructional materials is presented in Table 6.

Table 6: Levels of Utilization of Instructional Materials

\begin{tabular}{lll}
\hline Levels of the utilization of IM & Frequency & Percent \\
\hline Low & 62 & 37.9 \\
High & 102 & 62.1 \\
Total & $\mathbf{1 6 4}$ & $\mathbf{1 0 0 . 0}$ \\
\hline
\end{tabular}

According to Table 6, the researchers determined that $62.1 \%$ of the respondents achieved high levels, while $37.9 \%$ attained moderate levels of utilization of instructional materials in ECDE activity areas. These findings were consistent with those of Makokha (2017), where the level of utilization of improvised instructional materials was observed to be between moderate and high use in ECDE. The high level of utilization of improvised instructional materials was because the teachers had a vast experience, which was supplemented by the availability of the locally available resources within the school environment. These findings were further supported by those of Abaya (2017), where the level of utilization of instructional materials was observed to be high. The researcher observed that where instructional materials were available, the learners had no difficulties assimilating number concept.

\section{Hypothesis Test Results}

The null hypothesis stated that there was no statistically significant relationship between the teachers' attitudes and levels of utilization of IM in PPS in Nyeri County. To test this hypothesis, ChiSquare tests were conducted to establish whether there was a significant relationship between teachers' attitudes and utilization of instructional materials. The results of the Chi-Square Test are presented in Table 7.

Table 7: Chi-square results for teachers' attitudes and levels of utilization of instructional materials

\begin{tabular}{llll}
\hline $\begin{array}{l}\text { Level of Utilization of Instructional Materials } \\
\text { Teachers' Attitudes }\end{array}$ & Low & High & Total \\
\hline Positive Attitude & $35(21.5)$ & $100(60.9)$ & $135(82.4)$ \\
Negative Attitude & $27(16.4)$ & $2(1.2)$ & $29(17.6)$ \\
Total & $62(37.9)$ & $102(62.1)$ & $164(100)$ \\
\hline
\end{tabular}

$\chi^{2}=4.094 ;$ d.f. $=1 ; p=0.043^{*} ;$ Significant at $\mathrm{p}<0.05$

The results presented in Table 7 revealed that $60.9 \%$ of teachers who had positive attitudes achieved high levels of utilization of instructional materials in ECDE activities compared to only 1.2 $\%$ of teachers who had negative attitudes. The ChiSquare results $\left(\chi^{2}=4.094 ; \quad \mathrm{df}=2 ; \quad \mathrm{p}=0.043\right)$ demonstrated that there was a statistically significant relationship between teachers' attitude and level of utilization of instructional materials in ECDE. Further analysis was conducted using a simple linear regression model between teachers' 
attitudes and levels of utilization of instructional materials. The results are presented in Table 8.

Table 8: Regression Coefficients for teachers' attitudes

\begin{tabular}{|c|c|c|c|c|c|}
\hline \multicolumn{3}{|c|}{ Regression Coefficients for teachers' attitudes } & \multirow[b]{2}{*}{ Standardized Coefficients } & \multirow{3}{*}{$\mathbf{T}$} & \multirow{3}{*}{ Sig. } \\
\hline \multirow[t]{2}{*}{ Attitudes } & $\begin{array}{l}\text { Unstan } \\
\text { Coeffic }\end{array}$ & $\begin{array}{l}\text { ardized } \\
\text { nts }\end{array}$ & & & \\
\hline & B & Std. Error & Beta & & \\
\hline (Constant) & 10.799 & 3.414 & & 3.163 & .002 \\
\hline Positive & .516 & .147 & .266 & 3.506 & $.001 *$ \\
\hline Negative & .218 & .131 & .126 & 1.655 & .100 \\
\hline \multicolumn{6}{|c|}{$\begin{array}{l}\text { Dependent Variable: Levels of Utilization of IM } \\
\text { Predictor: Teachers' attitudes }\end{array}$} \\
\hline
\end{tabular}

Results presented in Table 8 indicated that there was a statistically significant relationship between teachers' positive attitudes and levels of utilization of instructional materials $(\beta=0.516 ; \mathrm{p}=0.001)$. These results indicated that teachers who had positive attitudes toward utilization of IM attained significantly higher levels of utilization of instructional materials in their classrooms compared to their counterparts who had negative attitudes. Therefore, it was concluded that the utilization of instructional materials in ECDE was significantly related to teachers' attitudes. The hypothesis stating that there was no statistically significant relationship between teachers' attitudes and utilization of IM was therefore rejected.

\section{DISCUSSION}

This study established that attitude had a statistically significant relationship with the utilization of instructional materials. These findings concurred with several studies done in other countries on the effect of teachers' attitudes to instructional practice. Al-Zaidiyeen, Mei and Fook (2010) investigated the level of ICT use for educational purposes by teachers in Jordanian rural secondary schools. The study demonstrated the importance of teachers' attitudes towards the use of ICT for educational purposes. A questionnaire was used for data collection and it was distributed among 650 teachers in Jordan. The survey included questions concerning the attitude of teachers towards the use of ICT. The findings revealed that teachers' level of ICT use for educational purposes was low, although their attitude towards ICT use was positive. Mueller and Wood (2012) in a study on patterns of beliefs and characteristics of teachers that influence computer-integration found that teachers' beliefs about ICT and technology integration influenced how they think about instructional media and hence how to use them during instruction. The results indicated that when teachers had positive beliefs about ICT, they were more likely to integrate the new technology in teaching.

A study by Yalcin, Kahraman and Yilmaz, (2011) on primary school teachers' use of instructional technologies self-efficacy levels underscored the importance of instructional materials in enhancing learning skills among the learners. These results indicated that teachers who had positive attitudes toward utilization of IM attained higher levels of utilization of instructional materials in their classrooms compared to their counterparts who had negative attitudes. Therefore, it was concluded that the utilization of instructional materials in ECDE varied significantly according to teachers' attitudes. The hypothesis stating that there was no statistically significant relationship between teachers' attitudes and utilization of IM was therefore rejected. These findings agreed with those of Achola, Gudo and Odongo (2016) that showed a significant relationship between teachers' attitudes and use of instructional materials in Kisumu County. The researcher observed that majority of the study participants responded positively to the extent to which they utilized the instructional materials in the classrooms. The results of a study by Njoki (2014) on the utilization of instructional media for quality 
training in pre-primary school teacher training colleges revealed that the contribution of tutors' attitude and motivation to the utilization of instructional media were highly significant. This implies that the increase in the level of motivation and attitude translated to an increase in the utilization of instructional materials. The results imply that the contribution of pre-primary school college tutors' attitude toward was significantly correlated to the utilization of instructional media.

\section{CONCLUSIONS AND RECOMMENDATIONS}

This study has shown that pre-primary school teachers' attitudes had a statistically significant relationship with the level of utilization of instructional materials. The outcome of this study has established that teachers' who had positive attitudes had higher levels of utilization of instructional materials than those who had negative attitudes. These results implied that teachers who had a positive attitude were more likely to use instructional materials than those teachers who had negative attitudes. This implies that a positive attitude is an important attribute of a pre-primary school teacher. It is recommended that continuous refresher teacher training and capacity building should be developed for pre-primary school teachers to promote the utilization of instructional materials in teaching and learning in early childhood education. Therefore, there is a need to inculcate positive attitudes towards the utilization of instructional materials among teachers during pre-service and in-service training sessions to promote best practices in instructional practice in pre-primary schools.

\section{ACKNOWLEDGEMENTS}

We wish to appreciate the support of the teachers who participated in this research.

\section{AUTHORS' CONTRIBUTIONS}

This manuscript is based on a $\mathrm{PhD}$ Thesis research conducted by the first author in partial fulfilment of a $\mathrm{PhD}$ degree under the supervision of the second and third authors. Both supervisors guided the entire research process from conceptualization to thesis completion. Besides, the co-authors contributed to the development and final approval of this manuscript.

\section{REFERENCES}

Abaya, H. M. (2017). Influence of instructional materials on pre-school children's learning achievement in number work in Matungu division, Kakamega County. Doctoral Dissertation. University of Nairobi.

Achola, O. R., Gudo, C. O. \& Odongo, B. (2016). Implications of instructional materials on oral skills among early childhood learners in central zone, Kisumu County, Kenya. International J. Educ. Pol., Res. Rev, 3 (2), 20-28.

Adebayo, O. O., \& Adigun, S. Q. (2018). Impact of Instructional Aids on Students' Academic Performance in Physics in Secondary Schools in Federal Capital Territory (FCT) Abuja, Nigeria. European Scientific Journal, ESJ, 14 (4), 366-376.

Afework, T. H., \& Asfaw, M. B. (2014). The availability of school facilities and their effects on the quality of education in government primary schools of Harari Regional State and East Hararghe Zone, Ethiopia. Middle Eastern \& African Journal of Educational Research, 11, 59-71.

Al-Zaidiyeen, N. J., Mei, L. L., \& Fook, F. S. (2010). Teachers' Attitudes and Levels of Technology Use in Classrooms: The Case of Jordan Schools. International education studies, 3 (2), 211-218.

Anini, F. (2011). Design and production of instructional materials made with leather for pre-school education in Ghana. Unpublished M.A. Thesis. Kwame Nkrumah University of Science and Technology, Kumasi, Ghana.

Bakr, S. M. (2011). Attitudes of Egyptian teachers towards computers. Contemporary Educational Technology, 2 (4), 308-318.

Barnard, J. (1998). Factors affecting the uptake of CAL in further education. Higher Education Close Up Conference. Preston: University of Central Lancashire. 
Bronfenbrenner, U. (1992). Ecological systems theory. In: R. Vasta (Ed.), Six theories of child development: Revised formulations and current issues (pp. 187-249). New York: Jessica Kingsley Publishers.

Cavas, B., Cavas, P., Karaoglan, B.\& Kisla, T. (2010). A study on science teachers' attitude toward information and education. The Turkish Online Journal of Educational Technology, 8:20-32.

Chacha, F., Mwanda, S., \& Midigo, R. (2017). Use of Instructional Media in Elementary Schools in Kenya: Understanding Teacher Attitude and Perceived Pedagogical Value of Picture Books. International Journal of Elementary Education, 6 (6), 53.

Chepkemoi, K. F. (2016). Factors influencing the Selection of Instructional Resources in Teaching Pre-Schools in Kenya. International Journal of Education and Research, 4 (11), 353-560.

Chepkonga, M. C. (2017). Influence of learning facilities on the provision of quality education in early childhood development centres in Kenya. International Journal of Education and Research, 5 (6), 15-26.

Digolo, O. C. (1986). A study of utilization of community resources of primary schools to provide relevance in education. Unpublished $\mathrm{Ph}$. D Thesis, Kenyatta University.

Karimi, A. (2012). A Study of instructional strategies and utilization of resources in social studies in primary teachers' Colleges in Kenya. Unpublished M. Ed. Thesis. Kenyatta University.

Kenya Institute for Curriculum Development (KICD) (2017). Pre-Primary One (PP1) Curriculum. Nairobi: KICD.

Kimui, W. (1990). A study of availability and use of learning and teaching resources in primary teachers' colleges in Kenya. Unpublished PhD Thesis. Kenyatta University.

Maddahian, E., \& Bird, M. (2004). Conceptual Framework for a Culturally Relevant and
Responsive Educational Model. Los Angeles Unified School District. Programme evaluation and research branch planning, assessment and research division. Publication No. 178.

Makokha, E. L. (2017). Determinants of preprimary school teachers' use of improvised materials in science instruction in Bungoma East Sub County, Bungoma County, Kenya. Doctoral Thesis. Kenyatta University.

Mayer, R. E. (2005). Cognitive theory of multimedia learning. In: Mayer, R. E. (Ed), The Cambridge Handbook of Multimedia Learning. New York: Cambridge University Press.

Msei, I. (1985). A survey of resources for teaching and learning of Kiswahili in some selected primary schools of Central Division Iveti South, Machakos District, Kenya. Unpublished M.Ed. Thesis, University of Nairobi.

Mueller, J., \& Wood, E. (2012). Patterns of beliefs, attitudes, and characteristics of teachers that influence computer integration. Education Research International, 2012.

Mugenda, O. \& Mugenda, A. (2003). Research methods: Quantitative and qualitative approaches. Nairobi: Acts Press.

Mwololo, J. N., Koech, B. G., Begi, N., \& Mutweleli, S. M. (2011). Pre-School Teachers' Knowledge and Attitude Towards Use of Visual Media In Instructional Delivery In Kibwezi District, Kenya. Journal of research in education and society, 2(1), 97-105.

Njoki, N. G. N. (2014). Utilization of instructional media for quality training in pre-primary school teacher training colleges in Nairobi County, Kenya. PhD Thesis, Kenyatta University.

Odejobi, C. O. (2014). A Comparative Study of Language Instructional Delivery System between Nursery Schools in Rural and Urban Areas in Osun State. World Journal of Education, 4 (5), 31-39.

Omayio, J. K. (2013). Effect of Instructional Resources on Children's Number Work Performance in Pre-Schools in Isibania Zone, 
Migori County. Doctoral Thesis. University of Nairobi.

Onadiran, G. T., \& Onadiran, R. W. (1981). Public library services in Nigeria. International library review, 13 (4), 409-433.

Wambua, M. (1988). A survey of resources for teaching and learning environmental education in primary teachers' colleges in Kenya. Unpublished M.Ed. P.T.E Project. Kenyatta University.

Yalcin, S. A., Kahraman, S., \& Yilmaz, Z. A. (2011). Primary school teachers and instructional technologies self-efficacy levels. Procedia-Social and Behavioural Sciences, 28, 499-502. 